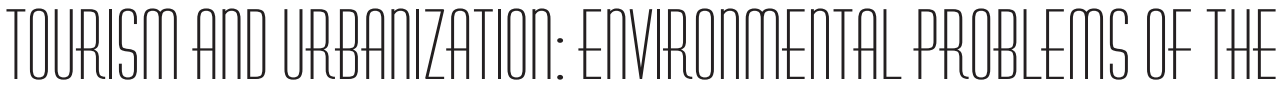

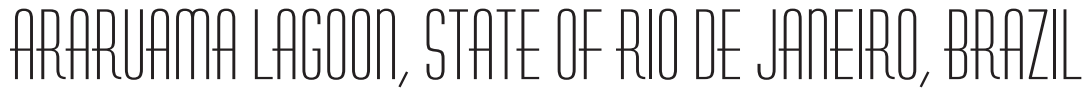

\author{
THAYSE CRISTINA PEREIRA BERTUCCI ${ }^{1}$ \\ EDSON PEREIRA SILVA ${ }^{2}$ \\ AGUINALDO NEPOMUCENO MARQUES JR. ${ }^{3}$ \\ CASSIANO MONTEIRO NETO 4
}

\section{1 - Introduction}

Coastal marine areas and estuary environments play a fundamental role in the socio-economic development of most societies. These environments are used in a variety of ways, from aquiculture to tourism and leisure. Also known as transition environments, they function as receptors and diluters of waste originating from human activity. Ecological, economic and, sometimes, evolutionary factors in this ecosystem have been widely discussed and studied (ESTEVES, 1998). For this reason, and because many species of commercial interest are frequently found in these environments, preservation initiatives abound (BARROSO e FABIANO, 1995).

Lagoon systems tend to be susceptible to climate and environmental changes, hydrological alterations and anthropogenic effects (LLORET et al., 2008; SILVA e ALMEIDA, 2012). It is important to highlight that many coastal environments are located in areas of high population density and, therefore, are subject to permanent stress (SOUZA et al., 2003; SILVA et al., 2008). Thus, many coastal lagoons have seen profound alterations to their original state, many suffering from deterioration, resulting in a variety of effects. Classic examples are the acceleration of eutrophication, changes in trophic resources, as well as negative impacts on the quality of habitats and biota (MARQUES et al., 2002). The Araruama Lagoon is not different from other lagoon environments in that it is also subject to man-made and environmental pressures (SANTIAGO e DESLANDES, 2011; CARVALHO et al., 2014).

1. Doutoranda em Biologia Marinha pela Universidade Federal Fluminense, Departamento de Biologia Marinha. E-mail: thathab@gmail.com

2. Doutor em Genética, Professor Adjunto da Universidade Federal Fluminense, Instituto de Biologia. E-mail: gbmedson@ vm.uff.br

3. Doutor em Geociencias, Professor Associado da Universidade Federal Fluminense, Departamento de Biologia Marinha. E-mail: aguinaldonepomuceno@id.uff.br

4. Doutor em Ciencias do Mar, Professor Titular da Universidade Federal Fluminense, Departamento de Biologia Marinha.E-mail: cmneto@id.uff.br 
Because of its beauty and plentiful natural and extractive resources, a number of activities take place in the municipalities surrounding the Araruama Lagoon, including tourism (SERRA e ALDER, 2006; SANTIAGO e DESLANDES, 2011). Tourists and holiday-makers almost double the population of the area during the hottest season and long weekends. Traditional activities, such as salt and shell (calcium carbonate) extraction as well as fishing, have been replaced by tourism and property speculation (MELO, 2011). The Lagoon began to be seen from a new economic perspective involving leisure and sports activities (TEIXEIRA, 2006). These new uses became more prominent from the 1960s onward when access to the Lagoon improved, due to better road infrastructure (HANSSEN, 1988; MELO, 2009; VAZ, 2012).

As a result, the region saw gradual changes and uncontrolled demographic growth, increasing man-made pressure and threatening the health of the Lagoon (SANTIAGO e DESLANDES, 2011; CARVALHO et al., 2014). The artificial introduction of fresh water and the discharge of untreated domestic effluents into the Lagoon altered the levels of fauna and flora density. It also caused changes in the Lagoon's water balance. It negatively affected the quality of the water system, threatening the whole lagoon and the activities taking place therein. In recent years, there have been many studies about the effects of these changes, highlighting the continuous process of cultural eutrophication of the environment (SOUZA et al., 2003; CARVALHO et al., 2014).

This work discusses the correlation between the socio-economic processes involving the development of cities, directly associated to the existence of the Araruama Lagoon, and its impact on the environmental quality of this ecosystem. The main aim is to develop an analysis that can correlate the social with the environmental worlds. Thus, the region's economic evolution will be analyzed by looking at two interrelated pairs of concepts: economic development/environmental degradation and economic decadence/ environmental preservation.

\section{2 - Methodology}

\subsection{Data characteristics}

This work is based on secondary data. Bibliographic research was conducted by using the Web of Knowledge, Scielo and Banco de Teses-CAPES databases. In order to do so, the following key words were used in both Portuguese and English: Lagoa de Araruama, tourism, property speculation and environmental history. All references found in this survey were analyzed.

The population growth index was used to establish a possible correlation between the environmental degradation of the Araruama Lagoon and advancing urbanization. This index was obtained by calculating the number of inhabitants in the five main cities surrounding the lagoon system: Araruama, Iguaba Grande, São Pedro da Aldeia, Cabo Frio and Arraial do Cabo. The study used data from the demographic census and population estimates available in the Brazilian Institute of Geography and Statistics site (IBGE, 2010). 


\subsection{Theoretical Frameworks}

In this study, the following theoretical frameworks were used for data analysis and interpretation. The first two, Political Ecology and Critical Environmental Education, are found in the works of Loureiro (2012) and other studies by the same author, as well as in the works of related authors. Generally speaking, these academics associate the environment with politics. Their perspective is that environmental problems are associated to the current means of production and consumption, based on a logic that involves unlimited accumulation (capital, profits and goods) and exacerbated consumption, inevitably leading to resources depletion and the accelerated destruction of the environment. Furthermore, this analysis also made use of environmental history, which investigates the complexities of the Man-nature relationship, where Man is not perceived as a separate entity from nature (WORSTER, 1991; LUNA et al., 2012).

When nature is seen as usable commodities, human history will be constructed through the commodification of the environment without taking into account nature's capacity for reproduction or even its resilience (SILVA, 2010; LUNA et al., 2012). Capitalist societies see the exploitation of the environment's natural resources as a means of capital accumulation either through tourism or extractive activities (MELO, 2009). In the capitalist economy, interactions are generally reduced to monetary value and focus on the increase of goods production to maximize profits (TEÓFILO et al., 2012). They are, therefore, associated to the permanent exploitation of nature. As a result, the deterioration of the environment is inevitable, jeopardizing not only natural resources, but also the existence of society as a whole (LOUREIRO, 2012).

\section{3- The Araruama Lagoon}

\subsection{The salt in the water}

The Araruama Lagoon (figure 1) is considered to be one of the largest permanent hypersaline lagoon ecosystems in the world (KJERFVE et al., 1996). Located in the coastal region of the State of Rio de Janeiro, $100 \mathrm{~km}$ from the city of Rio de Janeiro, the state capital, the Lagoon is within the State's Environmental Macroregion 4 and encompasses the municipalities of Araruama, Iguaba Grande, São Pedro da Aldeia, Cabo Frio and Arraial do Cabo (SEMADS, 2001). The Lagoon basin is approximately $220 \mathrm{~km}^{2}$ and runs alongside the Coast, separated from the sea by the extensive Massambaba Restinga (tropical coastal sandbank vegetation) to the south (COE NETO, 1984). 
Figure 1 - Map showing geographical location of the Araruama Lagoon.

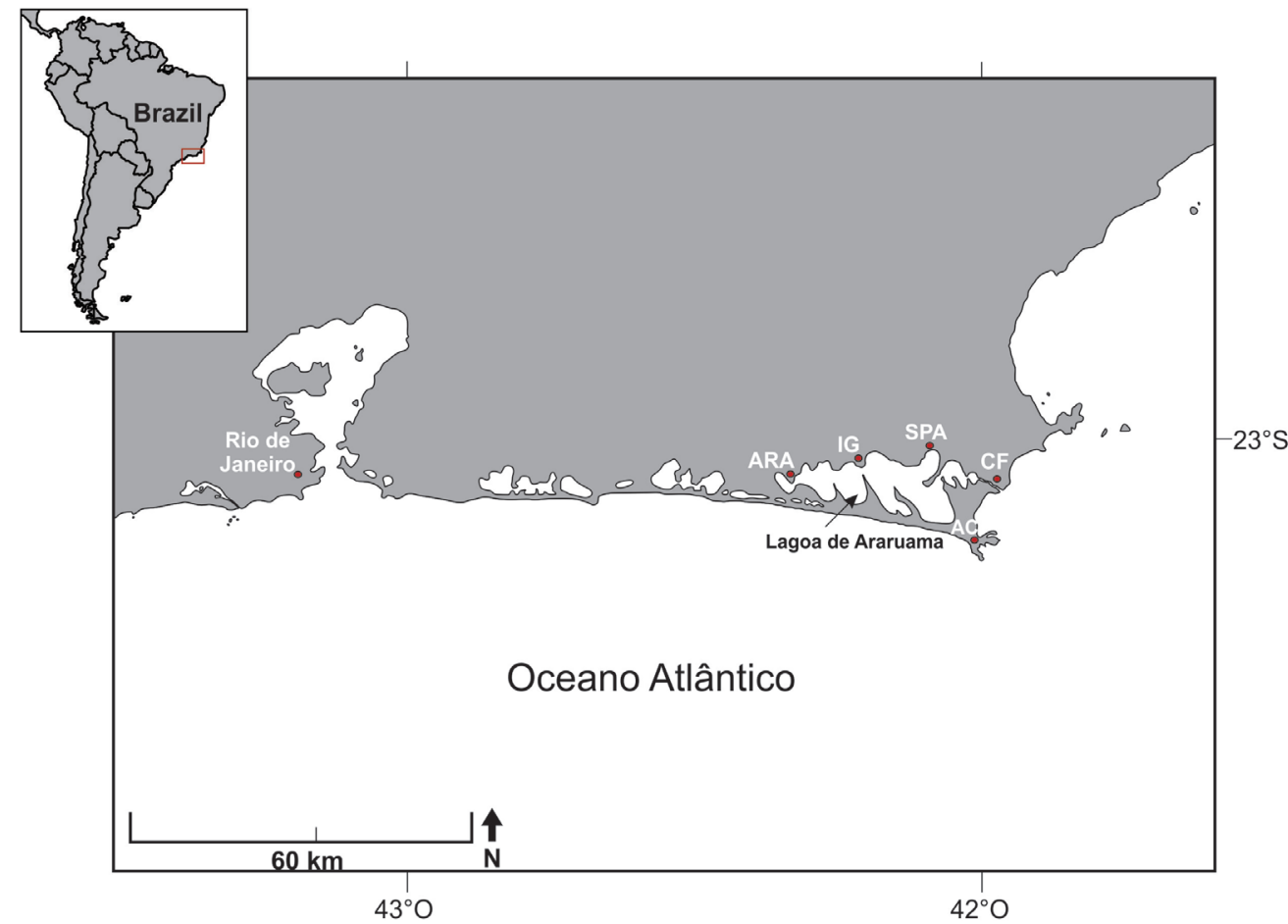

Subtitle: ARA - Araruama, IG - Iguaba Grande, SPA - São Pedro d'Aldeia, CF - Cabo Frio e AC - Arraial do Cabo.

Source: self elaboration.

The flow of most incoming rivers is negligible. The two main permanent rivers are located in the municipality of Araruama: the das Moças and the Mataruna rivers. The main waters feeding the lagoon tend mainly to flow from a single narrow canal, known as the Itajuru Canal, situated on the eastside of the basin (KJERFVE et al., 1996). Given the open and semi-enclosed compartments within the Lagoon, limited by spit outcrops, the Lagoon's salinity varies along the east-west axis, being always higher than that of sea water (KJERFVE et al., 1996).

Other elements that influence the Araruama Lagoon's hydrology include climatic factors. The lagoon system is located in a semiarid climatic region, with low rainfall and low freshwater flow compared with its total volume. Thus, the water balance in the Araruama Lagoon is considered negative since evaporation exceeds rainfall (BARBIÉRE, 1984). This is why it is classified as hypersaline (average salinity $=44.8$ ), a characteristic that remains constant throughout the year (KJERFVE et al., 1996; CILSJ, 2012). 


\subsection{Blue waters}

The Araruama Lagoon has always been considered one of the most important environments in the Região dos Lagos (The Lakes Region in the State of Rio de Janeiro), given its blue and crystalline waters, extensive beaches, mangrove, restinga and dune areas (BARROSO e FABIANO, 1995). The beauty of its landscape and scenery, associated to easy access, has resulted in the rapid and uncontrolled development of tourism (MELO, 2011).

From the 1960s, tourists and holiday-makers have been attracted to the Lagoon because of the region's low rainfall and high sunlight levels (ARTÁZCOZ, 2000; VAZ, 2012). For the first time, in 1970, a census conducted by IBGE revealed that the urban population of the region was larger than that of its rural areas. Consequently, the inversion of economic activities was a determining factor in the evolution of the quality of the local body of water (MOURA, 2011). The number of residents in the municipalities around the lagoon is doubled by the fluctuating population during the hot season and long weekends (VAZ, 2012).

Tourism became the most important economic activity in the region due to the area's close proximity to the large urban centers (ARTÁZCOZ, 2000; VAZ, 2012). The phenomenon of second homes emerged once the Rio-Niterói bridge and the Via Lagos (RJ-124) highway were built in the mid-1970s (ASSIS, 2003). Thus, many people sought to assuage their agitated lifestyles in the large urban centers by using the Araruama Lagoon region for holidays and weekends, facilitated by the quick access to the region (MELO, 2011).

At the time, the state and municipal governments also promoted tourism in the area, encouraging the recovery of old roads and the paving of new ones, as well as the regeneration of squares and leisure areas (TEIXEIRA, 2006). Furthermore, the emergence of intensive property speculation was a determining factor in the new logic of appropriation of the Lagoon's banks (MELO, 2011). In 1978, the National Congress set up a Parliamentary Committee Inquiry to investigate property speculation in the large centers. In Cabo Frio, there were allegations about the involvement of the municipalities surrounding the Lagoon in drainage works on Araruama's banks without due regard for the soil and the lagoon ecosystem (HANSSEN, 1988).

\subsection{Life in the salt}

In addition to its clear waters and excellent climatic conditions, the Araruama Lagoon is also a coastal environment with high biodiversity (SILVA e FERNANDES, 1994; SILVA et al., 2005), providing refuge for aquatic fauna, such as breeding grounds for fish, crustaceans and shellfish. The mangroves in this area also serve as shelter for many bird species (HANSSEN, 1988).

Most organisms found in the Lagoon are marine in origin. In some cases, the excessive salt reduces the size or limits the reproduction of species. Although the quantity of biomass is generally lower than in the sea, in certain places the amount of Lagoon 
fauna biomass can be quite large. Up to the 1990s, primary production, dominated by microphytobenthos, exceeded the production of phytoplanktons. This was the result of the low quantity of nutrients in the water column (COUTINHO et al., 1999). Animals such as sponges, bryozoa, cnidaria, amphipods, small nematodes and polychaetes are common (BIDEGAIN e BIZERRIL, 2002).

The Araruama Lagoon is still an important breeding ground for the Farfantepenaeus brasiliensis and F. paulensis shrimp species (GOMES et al., 2013). These crustaceans enter the Lagoon via the Itajuru Canal still in their post-larvae phase, aided by the rising tides, only returning to the sea after the fourth month of life to initiate their reproductive cycle. This closed habitat is also a haven for the development of 43 fish species. Some are born and remain in the Lagoon, such as the mojarra (Eugerres brasilianus), others return to the ocean after maturation to start their reproductive cycles, such as the mullet (Mugil liza) (BIDEGAIN e BIZERRIL, 2002).

The Lagoon's drainage basin is made up of several biomes that provide for the development of sectors such as agriculture, fishing, extractive activities and even tourism and leisure (BARROSO, 1987; SANTIAGO e DESLANDES, 2011).

\subsection{Ararú-Iama}

With over 40 species of fish (SAAD, 2003; MANSUR, 2010), it is not surprising that the Lagoon's first economic activity was artisanal fishing. It fostered the development of the urban centers in the region. Nowadays, the main fishing communities in the Lagoon are found in the municipality of São Pedro da Aldeia (VAZ, 2012).

As artisanal fishing gradually became economically less valuable, given the depletion in fish stocks and the reduction in water quality (SAAD, 2003), the Lagoon's economy started to depend on other activities, such as salt (in salt works) and shell extraction from the bottom of the Lagoon to produce lime and oyster shell flour. These activities benefitted from the environmental conditions of the lagoon system and were further boosted by the unblocking of the canal at the beginning of the last century (HANSSEN, 1988). Salt extraction became an important industry, yielding good harvests between August and March. However, strong competition from the northeast of Brazil in terms of salt extraction and manufacturing led to the gradual decline of this industry (HANSSEN, 1988).

Araruama means the 'abundance of shells' (in the Tupi language, ararú $=$ shells and iama = abundance), or "the lagoon of shells" (ALCOFORADO, 1936). The extraction of calcium carbonate from shells started when the National Alkali Company was created in 1952. However, it only became a regular activity at the beginning of the 1960s, with the first national production of soda ash. The increase in extraction in the Lagoon regenerated the economy of most municipalities, increasing employment opportunities in the tertiary sector such as trade and civil construction (VAZ, 2012).

These economic activities must also be taken into account when considering the development of tourism. Singular landscapes (fishing communities, windmills and white salt hills), the greater accessibility to the region and the search for new sites for leisure, entertainment and sports boosted the value of coastal areas, changing the identity of 
municipalities and their populations who, as a result, were affected by vigorous property speculation (MELO, 2011; SANTIAGO e DESLANDES, 2011).

With the increase in the value of space and the decline in salt production, the salt works were deactivated and land was allocated for property development (ARTÁZCOZ, 2000; VAZ, 2012). The predominance of tourism led to a dynamic transformation of the ecosystem because of the impacts of unplanned growth and development (SANTIAGO e DESLANDES, 2011). These factors led to silting in some regions of the Lagoon, damaging the quality of the environment in the system as a whole (CARVALHO et al., 2014).

\subsection{Freshwater pollution}

Water pollution is one of today's main environmental problems and is commonly associated to the discharge of domestic, industrial and agricultural effluents (MARQUES et al., 2002). In this case, the artificial introduction of freshwater and the discharge of untreated domestic and industrial waste into the Lagoon has persisted over a long period of time (KJERFVE et al., 1996). Alterations to the Lagoon's banks, in addition to the slow renewal rate of its waters, meant that untreated sewage remained at the bottom of the body of water for a long time. Although sewage stations were tendered to utility companies in 2000, operations only started in 2003, collecting sewage exclusively during the "dry season" (BIDEGAIN e BIZERRIL, 2002; CILSJ, 2012).

From the 1950s onward, but particularly since the construction of the Rio-Niterói Bridge in 1974 and the improvement of the access highways (RJ-104, 106), the uncontrolled demographic growth on the banks of the Lagoon resulted in increased man-made pressures on the ecosystem, threatening its environmental health (LIMA-GREEN, 2008; MELO, 2011). Occupation occurred in a chaotic manner, without due inspection by the municipal bodies. In addition, the introduction of freshwater used by the population led to changes in the system's conditions that are still felt today (MOREIRA-TURCQ, 2000).

The continuous discharge of sewage in natura in the Lagoon led to significant changes in environmental balance. An increase in the concentration of nutrients, in particular, phosphorus and nitrogen, resulted in a process known as cultural eutrophication due to the intensive urbanization observed recently in the region (SOUZA, 1997; CARVALHO et al., 2014). Effects vary and the acceleration of this process has led to changes in trophic resources and negative impacts on the quality of habitats and biota (MARQUES et al., 2002). Cultural eutrophication is becoming an increasingly serious issue and, possibly irreversible, resulting in lower water quality, threatening the whole lagoon system and the economic activities taking place therein (KJERFVE et al., 1996; COUTINHO et al., 1999; MELLO, 2007).

Souza (1997) proposed a conceptual model of potential events that could take place due to the persistent man-made impacts on the region. The model (Figure 2) suggests a rise in eutrophication due to population growth and the resulting increase in domestic effluent discharges in the body of water. The proposal shows that, in the future, there will be a change in the primary productivity from microphytobenthos to phytoplankton, 
and an increase in turbidity. Oxygen demand could lead to a drop in salinity and in the eutrophication of the lagoon system (SOUZA, 1997; KNOPPERS et al., 1999).

Figure 2 - Conceptual model proposed by Souza (1997) suggesting potential changes due to man-made activities in the future.

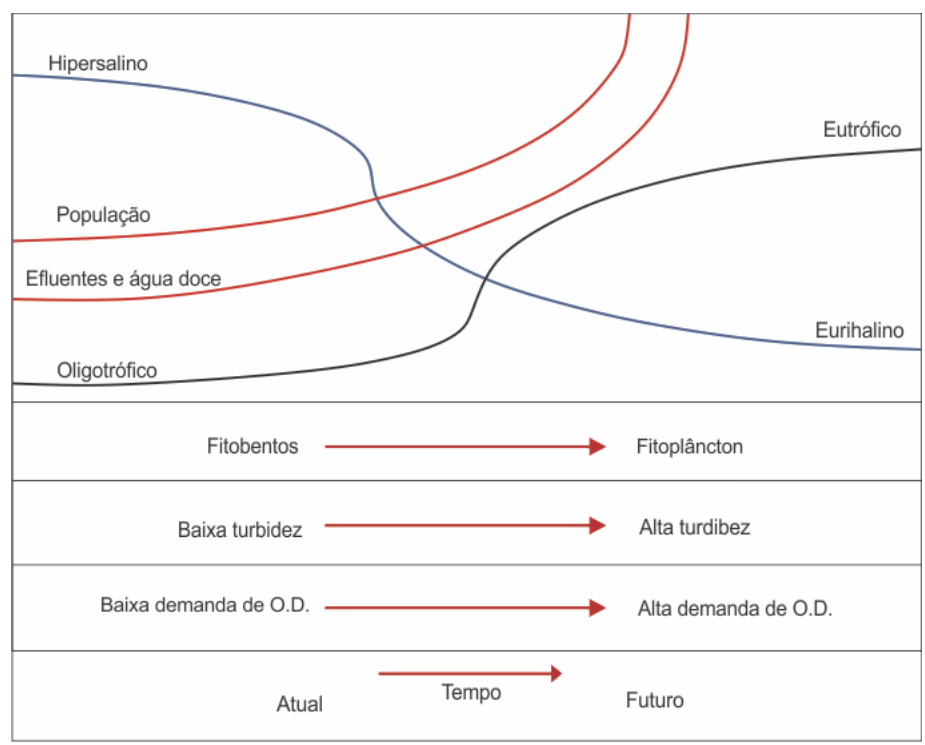

Source: Souza, 1997.

At the time, despite scientific warnings, no responsible bodies made any changes in relation to the organic load discharged in the Lagoon. A study conducted by Coutinho et al. (1999), indicated the existence of 365 direct effluent discharge points in the Lagoon. In the summer of 1997, the emergence of the over-proliferation of microalgae on Araruama's banks and changes in the nutritional conditions of the Lagoon corroborated the trends indicated by the above model (MELLO, 2007). Given the Lagoon's hypersalinity, eutrophication was delayed. This is because the high salinity of water results in a "buffer effect", hindering the growth of microalgae (GUERRA, 2009).

High levels of coliform concentration negatively affected water bathing standards and, therefore, tourism (ARTÁZCOZ, 2000). Furthermore, an increase in primary productivity temporarily raised the fish biomass and led to a fishing boom, resulting in the overfishing of specific fish species. This depleted fish stocks, affecting the Lagoon's fishing activities in the medium term (SAAD, 2003). The symptoms of this collapse were first felt when the self-cleaning capacity of the Lagoon reached its limit (VAZ, 2012).

In addition, the tertiary sector (trades and services) grew in line with a rise in the appropriation of the surface of the water (SILVA, 2008; MELO, 2009). Property speculation and the exploitation of tourism resulted in environmental degradation, caused by increased man-made impacts on the Lagoon's ecosystem (MELO, 2011). Economic activities such as extraction, fishing and leisure declined (for example, the National Alkali 
Company closed in 2006) (SAAD, 2003; PEREIRA, 2007). The lack of appropriate infrastructure and maintenance of the environment threatened the economic viability of the municipalities surrounding the Araruama Lagoon (COUTINHO et al., 1999; SAAD, 2003; VAZ, 2012).

\subsection{Saving the Lagoon}

Economic decadence, associated to the degradation of the region's environment and landscape, fostered the development of several government and civil society initiatives to monitor the Lagoon environment. In December 1986, an Environmental Protection Area (APA) was established on the southern side of the Massambaba Restinga, encompassing the municipalities of Saquarema, Araruama and Arraial do Cabo. The Massambaba State Ecological Reserve is found within this APA. A total of eight APAs were established in the areas surrounding the Lagoon to preserve the environmental characteristics of the water basin itself, as well as the whole environment encompassing the drainage basin of the Lagoon (ARTÁZCOZ, 2000).

In addition to these initiatives, in order to halt environmental deterioration and promote the recovery of the Araruama Lagoon ecosystem, the Lagos São João Intermunicipal Consortium (CILSJ) was created at the end of 1999. Thus, it was possible to bring together local governments, the State Environmental and Sustainable Development Department, private companies and NGOs, whose objective was environmental conservation (CILSJ, 2012).

The aim of the Consortium was to conduct environmental analysis to identify and monitor the long term natural resources of the Araruama Lagoon, by collecting data and mapping environmental, economic and social factors, on a regular basis. This program monitors water quality by analyzing a vast array of factors and biological processes. The work is conducted by a number of organizations. Technical parameters are measured and assessed by the Consortium and the water and sewage utility companies: Águas de Juturnaíba assesses the water in the municipalities of Silva Jardim, Saquarema, and Araruama, gathered from six collection points, while Prolagos monitors the municipalities of Armação de Búzios, Iguaba Grande, São Pedro da Aldeia, Arraial do Cabo and Cabo Frio (PEREIRA, 2007).

The aim of the Consortium, through these measures, is to recover the Araruama Lagoon ecosystem environment, by implementing programs and projects to improve this site and surrounding areas, as well as to promote the integration of governmental, private, third sector and civil society sectors (SERRA e ADLER, 2006; CILSJ, 2012).

\section{4 - Discussion}

\subsection{Man and Nature}

The first cycle of economic activities linked to the Araruama Lagoon (fishing, extraction, tourism) seems to be related to the pair of phenomena - economic development/ 
environmental degradation - strongly present in all the municipalities surrounding the Lagoon until the 1970s. These phenomena started to affect the main economic activity of the region at the time, tourism (TEIXEIRA, 2006). Within this context, the lack of understanding of the relationship of human beings with their environment resulted in the growing exploitation and alienation of the workforce in face of the deterioration of its source of wealth, nature (LUNA et al., 2012; TEÓFILO et al., 2012).

The need to accumulate capital means that man's production and consumption activities determine society. In a purely capitalist society, accumulation is based on the exploitation and alienation of the workforce, with a view to maximizing profits, without any concerns about the limits of nature (SILVA et al., 2008; LUNA et al., 2012). Inequality and injustice, resulting from this social framework are detrimental not only to the working classes, but also to nature, causing its degradation (LOUREIRO, 2012).

The lack of control of economic activities and their impacts on the environment, called by Marx the "scramble for nature", is considered one of the factors leading to the environmental crises the world is currently experiencing. This includes the crisis in the Araruama Lagoon. "Humanized Nature", that is, the environment seen as a man-made product, reveals not only the alienation of the workforce and a decline in its productive capacity, but also negative effects on the environment (ALTVATER, 2007). The result of violating the integrity of nature also negatively affects the production of surplus value. Thus, the State becomes implicated in defining measures for preserving the built environment, considered a means of production within capitalist society (MELO, 2009).

It is within this context that the concept of sustainable development becomes incorporated into the discourse of governments in an attempt to balance economic growth and environmental preservation. All the measures for preserving the Araruama Lagoon environment came about after the collapse of economic activities directly linked to it and not because of degradation per se. Within the capitalist logic, capital is the priority in detriment to man and nature.

Veiga (2005) claims that the concept of sustainable development is a 21st century utopia and argues for the need to find a new scientific paradigm to substitute it. According to him, many actions considered positive are in fact negative, because measures taken are not based on knowledge about the support and resilience capacity of these environments.

Dealing with environmental issues requires a critical analysis of the fundamental concepts of the capitalist system which favors the commodification of nature and contributes to fueling a predatory and devastating culture based on utilitarian suppositions (SILVA, 2010). In capitalist terms, the value of nature is rooted in the fact that it is necessary for economic development. Given that the Araruama Lagoon is an extremely productive environment with a high level of biodiversity, it falls within this conception. The reproductive capacity of capitalism is found in nature. However, the environment cannot produce goods without human labor. Therefore, the main discussion continues to involve the exploitation and the alienation of the workforce, something eco-developmentist discourses tend to ignore (VAZ, 2012).

For this reason, generally speaking, sustainable development proposals cannot surpass theory and, in practice, they ensure the continuous encroachment of man on the 
environment. That is, nature and Man continue to be conceived as commodities within the capitalist system and eco-development remains a fallacy (ANDRIOLI, 2008).

\subsection{The effect of population on the Lagoon's banks}

The way in which the population grows in a particular place affects the way in which nature and man live in harmony. This equilibrium can be maintained if there are measures to contain the disastrous consequences changes in the landscape can bring. Therefore, in order to assess the environmental quality of an ecosystem, both in space and time, it is essential to analyze population density (THOMAZIELLO, 2007).

The main problem in the Região dos Lagos is population density linked to its specific socio-cultural context. That is, it is seasonal and restricted to specific periods of the year (the summer season and long weekends) and particular locations (the northern part of the Lagoon, close to the Itajuru Canal) (SILVA, 2008). Following Vaz (2012), it can be observed that the ratio of occupied to non-occupied private residences in municipalities near the Lagoon is close to 1 (Table 1). With the exception of Iguaba Grande and Arraial do Cabo, the percentage of occupied residences is greater than non-occupied residences, on average 54\% (IBGE, 2010).

\section{Table 1 - Total $\mathbf{n}$. of residences in the municipalities close to Araruama Lagoon in comparison with a touristic town (AR) and a non-touristic town (NIT).}

\begin{tabular}{l|c|c|c|c|c|c|c}
\hline Homes & ARA & IG & SPA & CF & AC & AR & NIT \\
\hline $\begin{array}{l}\text { Occupied private } \\
\text { residences }\end{array}$ & 35,872 & 7,582 & 27,762 & 59,525 & 8,968 & 53,575 & 169,331 \\
$\begin{array}{l}\text { Non-occupied private } \\
\text { residences }\end{array}$ & 24,481 & 10,224 & 14,904 & 45,485 & 10,414 & 17,908 & 21,672 \\
$\begin{array}{l}\text { Collectives } \\
\text { Total }\end{array}$ & 56 & 2 & 45 & 365 & 64 & 573 & 169 \\
\hline
\end{tabular}

Subtitle: ARA - Araruama; IG - Iguaba Grande; SPA - São Pedro da Aldeia; CF - Cabo Frio; AC - Arraial do Cabo; AR - Angra dos Reis; NIT - Niterói. Source: Demographic Census (IBGE, 2010).

This shows that most existing residences in this region have an occupational use, and they represent almost $80 \%$ of all non-occupied private residences. The remainder refers to non-occupied residences. There are similarities in the distribution of the types of residences with another touristic town, Angra dos Reis. However, here there is a greater percentage of occupied residences, in comparison with the municipalities in the Lagoon, (74\%). By contrast, in the city of Niterói distribution is different, where approximately $90 \%$ of residences are occupied. Amongst those non-occupied, empty residences predominate (70\%, IBGE, 2010). 
Differences observed in terms of the distribution of residences seem to suggest that the uncontrolled growth on the banks of the Lagoon was driven by structural transformations in the region's economy and property speculation. According to some authors (LIMA-GREEN, 2008; MANSUR, 2010), this region presents the largest population growth in the state in recent decades and is thought to be the area suffering from the greatest urban pressure outside the metropolitan region.

These figures reinforce the conceptual model proposed by Souza (1997). In this way, urban growth associated to a lack of appropriate infrastructure has overloaded the ecosystem. A place that used to be oligotrophic has become hypertrophic, with a decrease in the salinity and an increase in turbidity of its waters (CARVALHO et al., 2014).

\subsection{Tourism}

The increase in the value of space and the transformation of the landscape in face of urban development means that tourism is one of the main factors in the degradation of the environment in most coastal towns (SLOB e WILDE, 2008; MELO, 2009). This is a serious issue, because environmental exploitation occurs far more quickly than the time it takes for the natural recovery and reproduction of the ecosystem, a far slower phenomenon. This is one of the most destructive aspects of the commodification of geographical spaces. In this case, particularly disturbing is the fact that the commodity value given to geographic spaces is also associated to their scarcity in terms of the beauty of the landscape and the scenery (CORREAA e FONTENELLE, 2010).

Restructuring the landscape, by using spaces in new ways is the direct result of tourism and property speculation (MELO, 2011). The actual transformation of the landscape occurs in an arbitrary way and without any planning that could have ensured the access of the population to basic services, such as drinking water, sewage, rain water drainage or space zoning plans. Thus, tourism, not only becomes a priority over the traditional activities in the region, but leads to the privatization of the public space (SILVA et al., 2008).

The Araruama Lagoon is a good example of this. Because of its beautiful scenery and high biodiversity, tourism and the continuing uncontrolled urban development of cities in the area have been determining factors in the environmental degradation of this ecosystem. A constant contradiction between the expansion of the economic sector and consumption vis-à-vis nature preservation can be observed in this region (SANTIAGO e DESLANDES, 2011; VAZ, 2012). According to Bohrer et al. (2009), the rate of deforestation on the banks of the Araruama Lagoon is a cause for concern. This is due to the building of resorts, property speculation and irregular occupation. The reduction in the original vegetation between 1961 and 2000 has reached 21\%. Similarly, water pollution in the Lagoon is of extreme concern according to the municipal bodies responsible for its management (The Lagos São João Intermunicipal Consortium - CILSJ).

Despite the implementation of sewage treatment systems by the utility companies - Prolagos and Águas de Juturnaíba - episodes of fish mortality and the accumulation of algae in the Lagoon's bays continue to be observed by local residents (Figure 3). 


\section{Figure 3 - Incidences of fish mortality and algae accumulation in the Lagoon's bays.}
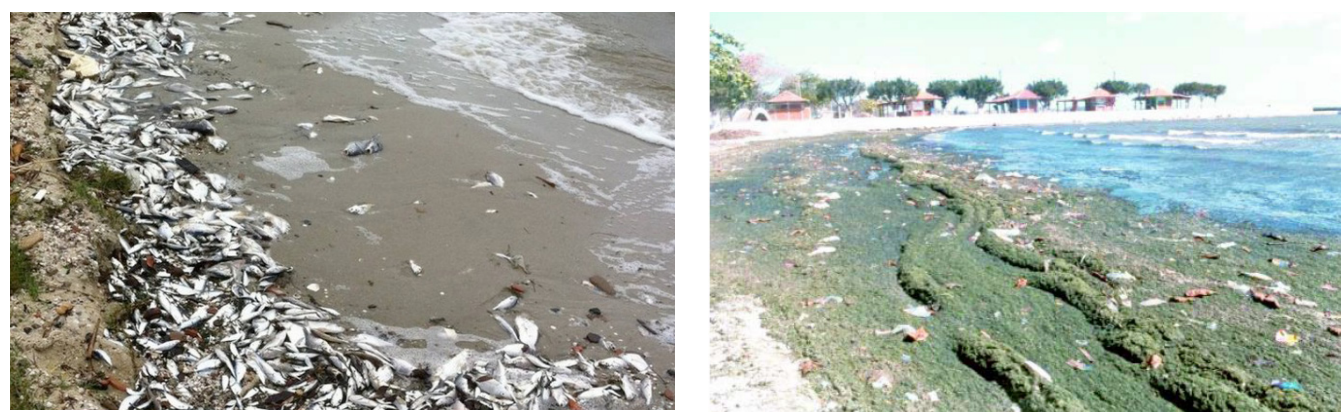

Source: Schmitt (2016); Bidegain e Bizerril (2002, p. 92).

The initial target of the utility companies (implement $70 \%$ of the sewage network in the surrounding municipalities) has been achieved and there are signs of progress in terms of the conditions in the Lagoon. However, this has not yet shown signs of effectiveness in terms of delaying the eutrophication process (CILSJ, 2012). It is within this context that a number of urban regeneration (such as improving the lagoon side infrastructure on the banks of the Massambaba Restinga - FEEMA, 2002) and environmental recovery (successive dredging in order to improve the water circulation - GARCIA et al., 2009) programs were implemented, in an attempt to improve the environmental conditions of the Araruama Lagoon.

However, it is worth remembering that most of these measures are driven by the need to maintain leisure activities in the Araruama Lagoon that were in decline. The tourism sector depends on the preservation of beauty and the main objective of these programs is to recover the rate of economic activity and generate capital for these municipalities (SILVA et al., 2008; LUNA et al., 2012).

It is, therefore, interesting to observe that current ecological awareness, geared toward environmental problems affecting the Araruama Lagoon, relate less to an actual change in the consciousness of governments and civil society, but have more to do with the old interests of capitalism. Mitigating measures meet the expansion interests associated to tourism, currently the main economic activity in the Lagoon (property speculation, commerce, etc.) (SERRA e ADLER, 2006; SANTIAGO e DESLANDES, 2011).

These seem to be the circumstances of the second cycle of economic activities linked to the Araruama Lagoon (property speculation and tourism), that is, the two phenomena of economic decadence/environmental preservation packaged in the ideological discourse of sustainable development. The environmental degradation observed in this ecosystem may result in a state of affairs that goes beyond the resilience of the Lagoon and the recovery capacity of the mitigating measures put in place by the local property and tourism sectors. Nevertheless, capitalist interests may survive for a long while, both because of the recreation of a sterile landscape and because of the productive forces put in practice to maintain a simulation of nature. 


\section{5 - Conclusion}

This paper described the environmental characteristics of the Araruama Lagoon, as well as the economic activities that took place within two specific periods, defined by the double phenomena of economic development/environmental degradation and economic decadence/environmental preservation.

In the first phase of the cycle, the economic activities linked to the Araruama Lagoon involved fishing, extraction and tourism. Nature was exploited as usable goods that were commodified without taking into account nature's reproductive capacity or its resilience. As a result, there was extensive degradation of the environment and this started to affect tourism.

The second cycle of economic activities (property speculation, tourism) is based on the sustainable development paradigm. That is, environmental degradation leads to economic decadence, requiring environmental preservation as a means of recovering the economic activities strongly linked to tourism and the property sector.

In the last 50 years, the Araruama Lagoon was negatively affected by new forms of appropriating space so as to meet the demands of tourism. In light of the value given to spaces, a preserved environment promotes economic activities and the generation of capital for the region. The planning of urban development and the organized occupation of spaces represent wealth and benefits for capitalist exploitation.

In order to address environmental issues related to the Araruama Lagoon, so as to break with the capitalist logic, necessarily requires the mobilization of the community to promote measures that assist with the recovery of this ecosystem. Community engagement is a complex task that depends on different ways of fostering social organization. In other words, it is important to consider biological, cultural and social diversity and oppose any homogeneity imposed by the capitalist market. In this way, environmental engagement depends on the introduction of a multiplicity of cultural manifestations and the empowerment of social movements. This means more emphasis on the public management of environmental issues as a way to ensure the social use of the environment. It is in this sense that this analysis of the historical cycles of the economic development of the Araruama Lagoon (the pairs of phenomena involving economic development/ environmental degradation and economic decadence/environmental preservation) hopes to provide a contribution.

\section{6 - References}

ALCOFORADO, P.G. O Sal Fluminense. Rio de Janeiro: Departamento de Estatística e Publicidade, 1936. 98 p.

ALTVATER, E. Existe um Marxismo Ecológico. In: BORON, A.A.; AMADEO, J.; GONZÁlEZ, S. (Org.) A teoria marxista hoje: Problemas e perspectivas. São Paulo: CLACS, 2007. 483 p. 
ANDRIOLI, A.I. A atualidade de Marx para o debate sobre a tecnologia e meio ambiente. Crítica Marxista. v. 27, p. 11-25, 2008.

ARTÁZCOZ, F. Lagoa de Araruama: Desafio Político e Conflitos Ambientais. Aspergillus - Pelo desenvolvimento sustentável (ONG), Rio de Janeiro: Ed.: Aspergillus, 2000. $91 \mathrm{p}$.

ASSIS, L.F. Turismo de segunda residência: a expressão espacial do fenômeno e as possiblidades de sua análise geográfica. Revista Território. Rio de Janeiro, v. 7, n. 11, 12, 13, set./out., p. 107-122, 2003.

BARBIÉRI, E.B. Cabo Frio e Iguaba Grande: Dois Microclimas Distintos a um Curto Intervalo Espacial. In: LACERDA, L.D.; ARAUJO, D.S.D.; CERQUEIRA, R.; TURCQ, B. (Eds). Restingas: Origem, estruturas e processos. Rio de Janeiro: CEUFF. 1984. p 3-13.

BARROSO, L.V. Diagnóstico Ambiental da Lagoa de Araruama - RJ. In: Fundação Brasileira para a Conservação da Natureza. Rio de Janeiro: Boletim FBCN, v. 22. 1987. p. 30-65.

BARROSO, L.V.; FABIANO, F.F.C. Estudo da pesca com artes fixas na Lagoa de Araruama. Oecolologia Brasiliensis. v. 1, p. 569-585, 1995.

BIDEGAIN, P.; BIZERRIL, C. Lagoa de Araruama - Perfil Ambiental do Maior Ecossistema Lagunar Hipersalino do Mundo. Rio de Janeiro: Semads, 2002. 160 p.

BOHRER, C.B.A.; DANTAS, H.G.R.; CRONEMBERGER, F.M.; VICENS, R.S.; ANDRADE, S.F. Mapeamento da vegetação e do uso do solo no Centro de Diversidade Vegetal de Cabo Frio, Rio de Janeiro, Brasil. Rodriguésia, v. 60, n. 1, p. 1-23, 2009.

CARVALHO, A.P.A.M.; COSTA, R.S.; ROSA, J.C.L. Eutrofização e introdução de espécies exóticas em estuário hipersalino: Lagoa de Araruama, Rio de Janeiro, Brasil In: SEMINÁRIO REGIONAL SOBRE GESTÃO DE RECURSOS HÍDRICOS, 4, 2014. Campos de Goytacazes. Anais... Rio de Janeiro, Campus Rio Paraíba do Sul - UPEA/ IFF. 2014. 13 p.

COE NETO, R. Algumas considerações sobre a origem do sistema lagunar de Araruama. In: LACERDA, L.D.; ARAUJO, D.S.D.; CERQUEIRA, R.; TURCQ, B. (Eds). Restingas: Origem, estruturas e processos. Rio de Janeiro: CEUFF. 1984. p. 61-63.

CONSÓRCIO INTERMUNICIPAL LAGOS SÃO JOÃO (CILSJ). Características Ambientais - Bacias Hidrográficas (Lagoa de Araruama). Disponível em: < http:// www.lagossaojoao.org.br/index-2.html>. Acesso em: 27 jul. 2012.

CORREAA, W.B.; FONTENELLE, T.H. Processo de ocupação da zona costeira: Ecoresorts e Gerenciamento Costeiro do Meso Compartimento Cabo Frio-Búzios, Litoral do Rio de Janeiro. In: ENCONTRO NACIONAL DE GEÓGRAFOS - CRISE, PRÁXIS E AUTONOMIA: ESPAÇOS DE RESISTÊNCIA E DE ESPERANÇAS, 16, 2010, Porto Alegre. Anais... Porto Alegre: ENG, 2010.

COUTINHO, R.; RIBEIRO, P.; KJERFVE, B.; KNOPPERS, B.; MUEHE, D.; VALENTIN, J.L. Araruama uma lagoa ameaçada. Ciência Hoje. v. 25, n. 149, p. 24-31, 1999. 
ESTEVES, F.A. Fundamentos de Limnologia. 2. ed. Rio de Janeiro: Interciência, 1998. $602 \mathrm{p}$.

FUNDAÇÃO ESTADUAL DE ENGENHARIA DO MEIO AMBIENTE (FEEMA). Plano Diretor Fundação Estadual de Engenharia de Meio Ambiente. Área de Proteção da Massambaba. Plano Diretor Rio de Janeiro: Governo do Estado Rio de Janeiro, Secretaria de Estado Planejamento Ambiental DEP 2002.

GARCIA, R.S.; TRANNIN, M.C.; GUEDES Jr, M. Considerações ambientais e sociais do ecossistema da Lagoa de Araruama. In: Encuentro de Geógrafos de América Latina, 13, 2009. Montevideo. Anais... Montevideo: Uruguai. 2009. 15 p.

GOMES, A.P.P.; KEUNECKEA, K.A.; SILVA Jr, D.R.; VIANNA, M. Modulating reproduction of Penaeidae shrimps: ecological responses of two sympatric species (Decapoda: Dendrobranchiata) on south-eastern Brazilian coast. Journal of the Marine Biological Association of the United Kingdom. v. 93, n. 3, p. 733-740, 2013.

GUERRA, L.V. Processos microbiológicos e composição da matéria orgânica relacionados à eutrofização de uma lagoa costeira hipersalina, L. Araruama, RJ. 2009. 108 f. Tese (Doutorado em Geoquímica Ambiental) - Universidade Federal Fluminense, Niterói. 2009.

HANSSEN, G. Cabo Frio: dos Tamoios a Álcalis. Rio de Janeiro: Ed. Achiamé, 1988. $239 \mathrm{p}$.

INSTITUTO BRASILEIRO DE GEOGRAFIA E ESTATÍSTICA (IBGE). Censo demográfico realizado em 2010. 2010. Disponível em: < http://censo2010.ibge.gov.br/>. Acesso em: 15 mar. 2014.

KJERFVE, B.; SCHETTINI, C.A.F.; KNOPPERS, B.; LESSA, G.; FERREIRA, H.O. Hydrology and salt balance in a large hypersaline coastal lagoon: Lagoa de Araruama, Brazil. Estuarine Coastal and Shelf Science. v. 42, p. 701-725, 1996.

KNOPPERS, B.; CARMOUZE, J.P.; MOREIRA-TURCQ, P.F. Nutrient Dynamics, Metabolism and Eutrophication of Lagoons along the East Fluminense Coast, State of Rio de Janeiro, Brazil. In: KNOPPERS, B.; BIDONE, E.D.; ABRÃO, J.J. (Eds). Environmental Geochemistry of Coastal Lagoon System, Rio de Janeiro, Brasil. Série Geoquímica Ambiental, v. 6, p. 123-154. 1999.

LIMA-GREEN, A. P. Análise politico-institucional da gestão das aguas na Bacia Lagos Sào João, RJ. 2008. 133 f. Dissertação (Mestrado Profissional em Engenharia Ambiental) Faculdade de Engenharia, Universidade do Estado do Rio de Janeiro, Rio de Janeiro, 2008.

LLORET, J.; MARÍN, A.; MARÍN-GUIRAO, L. Is coastal lagoon eutrophication likely to be aggravated by global climate change? Estuarine, Coastal and Shelf Science. v. 78, p. 403-412, 2008.

LOUREIRO, C.F.B. Sustentabilidade e educação: um olhar da ecologia política. São Paulo: Cortez Editora, 2012. 128 p. 
LUNA, E.M.; BRASIL, A.A.; MÁXIMO, B.P. Marxismo e Ecologia: Uma Crítica a Economia Verde. In: SEMANA DE ECONOMIA POLÍTICA, GT9 - ECOLOGIA E MARXISMO, 1, 2012. Fortaleza. Anais... Fortaleza: Universidade Federal do Ceará, 2012. 7 p.

MANSUR, K.L. Diretrizes para geoconservação do patrimônio geológico do estado do Rio de Janeiro: o caso do domínio tectônico de Cabo Frio. 2010. 249 f. Tese (Doutorado em Geografia) - Instituto de Geociências, Universidade Federal do Rio de Janeiro, Rio de Janeiro. 2010.

MARQUES Jr., A.N.; MORAES. R.B.C.; MAURAT. M.C. Poluição Marinha. In. PEREIRA, R.C.; SOARES-GOMES, A. (Eds.). Biologia Marinha. 2002. p. 311-334.

MELLO, T.B.M. Caracterização biogeoquímica da Lagoa de Araruama, RJ. 2007.82 f. Dissertação (Mestrado em Geoquímica Ambiental) - Universidade Federal Fluminense, Rio de Janeiro, 2007.

MELO, E.S.O. Gênese da Urbanização Turística em Cabo Frio (1950-1978). In: ENCONTRO NACIONAL DA ANPUR. 14, 2011. Rio de Janeiro. Anais... Rio de Janeiro, 2011. $20 \mathrm{p}$.

MELO, E.S.O. Turismo Para Quem? Conflitos Acerca da Manipulação de Fluxos e da Produção dos Espaços Turísticos. In: ENCONTRO DA ASSOCIAÇÃO NACIONAL DE PÓS-GRADUAÇÃO E PESQUISA EM PLANEJAMENTO URBANO E REGIONAL, 13, 2009. Florianópolis. Anais... Florianópolis: Santa Catarina, Brasil. 2009. 20 p.

MOREIRA-TURCQ, P.F. Impact of a low salinity year on the metabolism of a hypersaline coastal lagoon (Brazil). Hydrobiologia. v. 429, p. 133-140. 2000.

MOURA, R.P. E o mar vai virar aterro antropologia, direito e conflito nas disputas por espaços num bairro do interior fluminense. In: ENCONTRO NACIONAL DE ANTROPOlOGIA DO DIREITO, 2, 2011, São Paulo. Anais... São Paulo: Ed USP. 2011. n. 4, 15 p.

PEREIRA, L.F.M. A gestão participativa no caso do saneamento da Região dos Lagos, Rio de Janeiro. Revista Discente Expressões Geográficas, v. 3, p. 10-41. 2007.

SAAD, A.M. Composição, Distribuição Espacial, Dinâmica de Populações de Peixes e Estatística Pesqueira na Lagoa de Araruama, RJ. 2003. 105 f. Tese (Doutorado em Ecologia e Recursos Naturais) - Universidade Federal de São Carlos, São Carlos. 2003.

SANTIAGO, R.B.; DESLANDES, R. Politicas Públicas e Ordenamento Territorial em Áreas de Preservação Ambiental na Região dos Lagos, Rio de Janeiro. Revista Geográfica de América Central. Número Especial EGAL, Costa Rica, II Semestre. p. 1-8, 2011.

SCHMITT, L.G. Lagoa de Araruama enfrenta nova mortandade de peixes. 2016. Disponível em: < http://oglobo.globo.com/rio/lagoa-de-araruama-enfrenta-nova-mortandade-de-peixes-18922712\#ixzz46Br5jZIU>. Acesso em: 13 abr. 2016.

SECRETARIA DE ESTADO DE MEIO-AMBIENTE E DESENVOLVIMENTO SUSTENTÁVEL (SEMADS). Bacias Hidrográficas e Rios Fluminenses - Síntese Informativa por Macrorregião Ambiental. Rio de Janeiro: Semads, 2001. 73 p. 
SERRA, A.C.; ADLER, C.S. Gerenciamento Ambiental na Região dos Lagos Promove o Desenvolvimento Sustentável Com Responsabilidade. In: CONGRESSO NACIONAL DE EXCELÊNCIA EM GESTÃO, 3, 2006, Niterói. Anais... Niterói, 2006. 17 p.

SILVA, E.P.; FERNANDES, F.C. A vida no sal. Ciência Hoje. v. 18, n. 104, p. 74-75, 1994.

SILVA, E.P.; FERNANDES, F.C.; SOARES-GOMES, A.; ABREU, C.M. Sandy beach macrobenthos assemblages at a hypersaline coastal lagoon, Lagoa de Araruama, RJ, Brasil. Journal of Coastal Research, v. 42, n. SI, p. 265-270, 2005.

SILVA, F.M.; ALMEIDA, L.Q. Uma Abordagem sobre a Vulnerabilidade Socioambiental no Ambiente Estuarino: Aspectos Teórico - Conceituais. Revista Geonorte, Edição Especial. v. 1, n. 4, p. 102-112, 2012.

SILVA, J.M.C.; BOZELLI, R.L.; SANTOS, L.F.; LOPES, A.F. Impactos Ambientais da Exploração e Produção de Petróleo na Bacia de Campos, RJ. In: ENCONTRO NACIONAL DA ANPPAS, 4. 2008. Brasília. Anais... Brasília. 2008. 19 p.

SILVA, M.G. Questão ambiental e desenvolvimento sustentável: um desafio ético político ao serviço social. São Paulo: Cortez, 2010. 256 p.

SILVA, S.E.C.P. Uso e cobertura da terra relacionados à eutrofização da Lagoa Hipersalina de Araruama, RJ. 2008. 64 f. Dissertação (Mestrado em Geociências) - Universidade Federal Fluminense, Rio de Janeiro, 2008.

SLOB, B.; WILDE, J. Turismo e sustentabilidade no Brasil - A cadeia de valor do turismo em Porto de Galinhas, Nordeste do Brasil. Rio de Janeiro: SOMO - Centro de Pesquisa em Empresas Multinacionais, 2008.

SOUZA, M.F.L.; BJORN, K.; KNOPPERS, B.; SOUZA, W.F.L.; DAMASCENO, R.N. Nutrient budgets and trophic state in a hypersaline coastal lagoon: Lagoa de Araruama, Brazil. Estuarine Coastal and Shelf Science. v. 57, p. 843-858, 2003.

SOUZA, W.F.L. Dinâmica de nutrientes na laguna hipersalina de Araruama, RJ. 1997. 174 f. Dissertação (Mestrado em Geociências) - Universidade Federal Fluminense, Rio de Janeiro, 1997.

TEIXEIRA, V.M.L. A cidade e a lagoa: memória e identidade urbana em Araruama. 2006. 140 f. Dissertação (Mestrado em Geografia) - Universidade Federal Fluminense, Rio de Janeiro, 2006.

TEÓFILO, R.M.T.; SOUZA, F.G.; JIMENEZ, S. Crise Ambiental: uma análise preliminar perspectivada no materialismo histórico dialético. In: SEMANA DE ECONOMIA POLÍTICA, GT9 - ECOLOGIA E MARXISMO. 1, 2012. Fortaleza. Anais... Fortaleza: Universidade Federal do Ceará, 2012. 7 p.

THOMAZIELLO, S. Usos da Terra e sua influência sobre a Qualidade Ambiental. In: SANTOS, R.F (Org.). Vulnerabilidade Ambiental: Desastres Naturais ou Fenômenos Induzidos? Brasília: MMA, 2007. p. 23-38. 
VAZ, A.J. A Bacia Hidrográfica Lagos - São João pós década de 1960: um estudo das transformações espaciais da região e suas influências sobre a qualidade ambiental. 2012. 127 f. Dissertação (Mestrado em Geografia) - Instituto de Geografia, Universidade Estadual do Rio de Janeiro, Rio de Janeiro. 2012.

VEIGA, J.E. Cidades Imaginárias - o Brasil é menos urbano do que se calcula. Campinas: Editora da Unicamp, 2005. 304 p.

WORSTER, D. Para fazer história ambiental. Revista Estudos Históricos. v. 4, n. 8, p. 198-215, 1991.

Submitted on: 30/06/2014

Accepted on: 19/07/2016

http://dx.doi.org/10.1590/1809-4422ASOC137111V1942016 



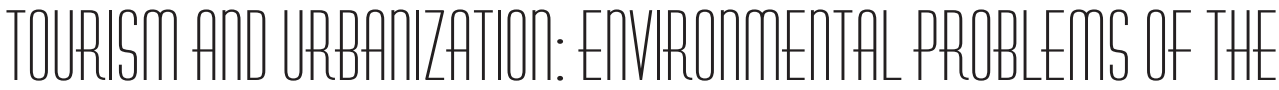

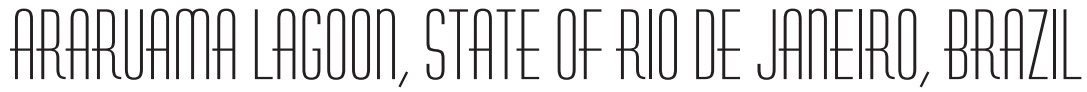

\author{
THAYSE CRISTINA PEREIRA BERTUCCI \\ EDSON PEREIRA SILVA \\ AGUINALDO NEPOMUCENO MARQUES JR. \\ CASSIANO MONTEIRO NETO
}

\begin{abstract}
The Araruama Lagoon (Rio de Janeiro) is known for its scenic beauty and natural resources, factors that have led to the economic expansion of the region. In recent decades, tourism and property speculation have been key to the urban development of the municipalities surrounding this Lagoon. Using secondary data and a theoretical framework based on Political Ecology and Critical Environmental Education, this article seeks to analyze the correlations between the development processes of the towns surrounding the Lagoon and the impact of these processes on the environmental quality of its ecosystem. In recent years, the evolution of parameters studied revealed that the imbalance in terms of the sustainable development of the region has damaged the health of this body of water. Large quantities of fresh water, as well as domestic and industrial effluents discharged without appropriate treatment in the Lagoon, have overloaded the ecological system, with negative effects for the entire economy in the surrounding area.
\end{abstract}

Key words: Tourism; Man-nature relations; Urbanization; Environmental Degradation; Araruama Lagoon.

Resumo: A Lagoa de Araruama (Rio de Janeiro) é conhecida por sua beleza cênica e recursos naturais, fatores que permitiram a expansão econômica da região. A atividade turística e a especulação imobiliária foram determinantes para o desenvolvimento urbano dos municípios adjacentes nas últimas décadas. Utilizando dados secundários e o referencial teórico a Ecologia Política e da Educação Ambiental Crítica, buscou-se avaliar as correlações entre o processo de desenvolvimento das cidades as margens da Lagoa e o seu impacto sobre a qualidade ambiental deste ecossistema. A evolução dos parâmetros estudados ao longo dos últimos anos demonstrou que o desequilíbrio do desenvolvimento sustentável na região prejudicou a saúde do corpo hídrico. A elevada taxa de introdução artificial de água doce e de efluentes domésticos e industriais, sem o tratamento adequado, sobrecarregou o sistema lagunar; prejudicando, assim, toda a economia adjacente. 
Palauras-chave: Turismo. Relação homem-natureza. Urbanização. Degradação Ambiental. Lagoa de Araruama.

Resumen: La Laguna de Araruama, situada en la costa del estado de Río de Janeiro, es conocido por su belleza escénica y los recursos naturales, y permitieron que la región expandir económicamente. El turismo y la especulación inmobiliaria fueron la clave para el desarrollo urbano de los municipios adyacentes en las últimas décadas. El presente estudio intenta una evaluación de las correlaciones entre los procesos de desarrollo de las ciudades relacionadas con la laguna de Araruama y su impacto en la calidad ambiental de este ecosistema. Se basa en una revision de la literatura e usada la teoria Política Ecología teórica y Educación ambiental crítica. La evolución de los parámetros estudiados en los últimos años ha demostrado que el desequilibrio del desarrollo sostenible en la región deterioro la salud de la masa de agua. La alta tasa de introducción artificial de agua dulce y aguas residuales domésticas e industriales, sin tratamiento adecuado, ha sobrecargas el sistema lagunar; causando, por ello, un perjuicio a toda la economía circundante.

Palabras clave: Turismo. Relación hombre-naturaleza. Urbanización. Degradación ambiental. Laguna de Araruama. 